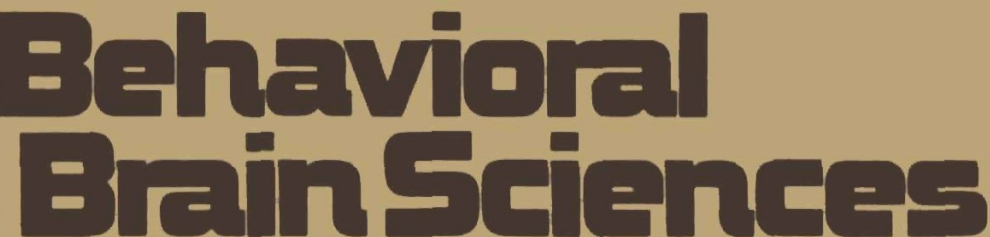

An International Journal of Current Research and Theory with Open Peer Commentary

VOLUME 6 / NUMBER 2 / JUNE 1983

Brain organization for language from the perspective of electrical stimulation mapping

George A. Ojemann

With Commentary by F Boller; JW Brown; HW Buckingham, Jr.; WH Calvin; PS Churchland; WE Cooper; L Frazier; RD Kent; WG Lehnert; AM Liberman; JC Marshall; JD Newman; M Studdert-Kennedy; P Tallal; F Wood; and Author's Response

\title{
Rational belief
}

Henry E. Kyburg, Jr.

With Commentary by JE Adler; M Bar-Hillel \& A Margalit; LJ Cohen; J Dorling; JStBT Evans; G Harman; WL Harper; PN Johnson-Laird; D Kahneman; I Levi; LL Lopes; D Miller; RE Nisbett \& P Thagard; P Pollard; R Revlin; T Seidenfeld;

S Spielman; RD Tweney, ME Doherty \& CR Mynatt; and Author's Response

\section{An analysis of psychotherapy versus placebo studies \\ Leslie Prioleau, Martha Murdock, and Nathan Brody \\ With Commentary by G Andrews; DS Cordray \& RR Bootzin; H Dahl; \\ RM Dawes; MN Eagle; E Erwin; HJ Eysenck; JM Fish; JD Frank; SL Garfield; \\ GV Glass, ML Smith \& TI Miller; RP Greenberg; LV Hedges; AE Kazdin; \\ P Kline; B Maher; R Rosenthal; TL Rosenthal; TA Sebeok; DA Shapiro; \\ M Shepherd; DP Spence; GT Wilson; and Authors' Response}

Continuing Commentary on Jensen: "Test bias"; Warren:

"Sensory intensity"; Rachlin et al.: "Maximization behavior"; Bernstein: "Social dominance"; Colby: "Modeling paranoia" 


\section{The Eshavioral and Brainsciencess}

Editor

Stevan Harnad

20 Nassau St., Suite 240

Princeton, NJ08540

\author{
Assistant Editor \\ Helaine Randerson \\ Associate Editors \\ Behavioral Biology \\ Jack P. Hailman/U. Wisconsin \\ Hubert Markl/Universität Konstanz \\ Biosocial Behavior \\ Glendon Schubert U. Hawaii, Manoa \\ Cognition and Artificial Intelligence \\ Zenon Pylyshyn/U. Western Ontario \\ Cognitive Development \\ Annette Karmiloff-Smith/MRC, London and MPI, Nijmegen \\ Cognitive Neuroscience \\ Lynn Nadel/U. California, Irvine \\ Developmental Psychology \\ Charles J. Brainerd/U. Western Ontario \\ Evolutionary Biology \\ Michael T.Ghiselin/California Academy of Sciences \\ Experimental Analysis of Behavior \\ A. Charles Catania/U. Maryland, Baltimore County
}

History and Systems

Julian Jaynes/Princeton

Language and Cognition

Peter Wason/University College, London

Language and Language Disorders

Max Coltheart U. London

Neurobiology

Graham Hoyle/U. Oregon

Neuropharmacology

Susan D. Iversen/U. Cambridge

Neuropsychology

Jeffrey A. Gray/U. Oxford

Neurophysiology

Sten Grillner/Károlinska Institutet

Paleoneurology

Stephen Jay Gould/Harvard

Philosophy

Daniel C. Dennett/Tufts

Psychobiology

Victor H. Denenberg/U. Connecticut

David S. Olton/Johns Hopkins

Quantitative Methods

Donald B. Rubin/U. Wisconsin

Vision and Artificial Intelligence

Stuart Sutherland/U. Sussex
Editorial Policy The Behavioral and Brain Sciences (BBS) is an international journal providing a special service called Open Peer Commentary* to researchers in any area of psychology, neuroscience, behavioral biology, or cognitive science who wish to solicit, from fellow specialists within and across these BBS disciplines, multiple responses to a particularly significant and controversial piece of work. (See Instructions for Authors and Commentators, inside back cover.) The purpose of this service is to contribute to the communication, criticism, stimulation, and particularly the unification of research in the behavioral and brain sciences, from molecular neurobiology to artificial intelligence and the philosophy of mind.

Papers judged by the editors and referees to be appropriate for Commentary are circulated to a large number of commentators selected by the editors, referees, and author to provide substantive criticism, interpretation, elaboration, and pertinent complementary and supplementary material from a full crossdisciplinary perspective. The article, accepted commentaries, and the author's response then appear simultaneously in BBS.

Commentary on BBS articles may be provided by any qualified professional in the behavioral and brain sciences, but much of it is drawn from a large body of BBS Associates who have become formally affiliated with the project.

Qualified professionals are eligible to become BBS Associates if they have (1) been nominated by a current BBS Associate, (2) refereed for BBS, or (3) had a commentary or article accepted for publication. A special subscription rate is available to Associates. Individuals interested in serving as BBS Associates are asked to write to the editor.

This publication was supported in part by NIH Grant LM 03539 from the National Library of Medicine.

"Modelled on the 'CA Comment' service of the journal Current Anthropology.
Copying This journal is registered with the Copyright Clearance Center (21 Congress St., Salem, MA 01970). Organizations in the U.S.A. who are also registered with the CCC may therefore copy material (beyond the limits permitted by sec. tions 107 and 108 of U.S. Copyright Law) subject to payment to the CCC of the per-copy fee indicated in the code on the first page of the article. This consent does not extend to multiple copying for promotional or commercial purposes.

ISI Tear Sheet Service, 325 Chestnut Street, Philadelphia. PA 19106, is authorized to supply single copies of separate articles for private use only.

For all other use, permission should be sought from the Cambridge or New York offices of the Press.

Subscriptions The Behavioral and Brain Sciences (ISSN 0140-525X) is published quarterly in March, June, September and December. Four parts form a volume. The subscription price, which includes postage, of Volume 6 (1983) is US $\$ 97.00$ net in the U.S.A. and Canada ( $\$ 59.00$ in the U.K. and rest of the world) for institutions; US $\$ 49.50$ net $(£ 30.00)$ for individuals; US $\$ 30.00$ net ( $(19.00$ ) for BBS Associates; and US $\$ 30.00$ net for students (in the U.S.A. and Canada only) who provide proot of eligibility with order. Single parts cost US $\$ 27.00$ net $(\{17.00)$ plus postage. Institutional orders may be sent to a bookseller or, in the U.S.A. and Canada direct to: Cambridge University Press, 32 East 57 Street, New York, N.Y. 10022; in the U.K. and rest of the world to: Cambridge University Press, The Edinburgh Building, Shaftesbury Road, Cambridge CB2 2RU. England. Individuals must order direct from the Press. Second class postage paid at New York, N.Y and at additional mailing offices. Postmaster: send address changes in the U.S.A. and Canada to BBS. Cambridge University Press, 32 East 57 Street, New York, N.Y. 10022.

Advertising Inquiries about advertising should be sent to the Journals Promotion Department of the Cambridge or New York office of Cambridge University Press 